\title{
Effects of Changes in Osmolarity on the Biological Activity of Human Normal Nucleus Pulposus- Derived Mesenchymal Stem Cells
}

\section{Hua Zhang}

Anhui Medical University

Wei Li

Anhui Medical University

Shengquan Zhang

Anhui Medical University

Jie Li

Anhui Medical University

\section{Letian Han}

Anhui Medical University

\section{Haoyu Chen}

Anhui Medical University

\section{Ziyu Wang}

Anhui Medical University

Cailiang Shen

Anhui Medical University

Yinshun Zhang

Anhui Medical University

Hui Tao ( $\square$ taohspine@163.com )

Anhui Medical University

\section{Research}

Keywords: Intervertebral disc degeneration, Human nucleus pulposus mesenchymal stem cells, Osmolarity, Biological activity,P16INK4A

Posted Date: May 6th, 2021

DOI: https://doi.org/10.21203/rs.3.rs-462338/v1

License: (c) (i) This work is licensed under a Creative Commons Attribution 4.0 International License. Read Full License 
Version of Record: A version of this preprint was published at Stem Cells International on April 23rd, 2022. See the published version at https://doi.org/10.1155/2022/1121064. 


\section{Abstract}

Background:The expansion and differentiation of nucleus pulposus-derived mesenchymal stem cells \NPMSCs $₫$ are considered as potential therapeutic tools for clinical applications in intervertebral disc tissue engineering and regenerative medicine.However, the harsh microenvironment within the intervertebral disc is the main limitation of its regeneration. The osmolarity of the intervertebral disc is higher than that of other tissues, which has an important influence on the biological characteristics of NPMSCs. In this study,we observed the effect of different osmolarities on the biological characteristics of human normal NPMSCs cultured in vitro and explored the role of osmolarity in intervertebral disc degeneration.

Methods: NPMSCs were isolated from the lumbar intervertebral disc (Pfirrmann I or II) of patients with lumbar fractures by collagenase digestion, and nucleus pulposus-derived stem cells were isolated, cultured and passaged in vitro. The isolated cells were identified by immunophenotype and multilineage differentiation. Then, the cells were cultured under conditions with different osmotic pressures. The cell proliferation rate, apoptosis rate, cell cycle status and cell senescence were detected, and the expression of stemness genes (Nanog, Notch1, Jag1, OCT4), functional genes (Aggrecan, Collagen II) and the $\mathrm{P} 16^{\mathrm{INK} 4 \mathrm{~A}}$ and RB genes was detected. siRNA transfection was used to determine the role of the $\mathrm{P} 16^{\mathrm{INK} 4 \mathrm{~A}} / \mathrm{RB}$ signaling pathway in the effect of changes in osmotic pressure on cells.

Results: The experimental results demonstrated that the isolated cells met the standards of the International Society for Cell Therapy. The cells we isolated and cultured from the intervertebral discs are NPMSCs. Our work showed that low and high osmotic pressure can inhibit cell proliferation, promote cell apoptosis, block cell cycle progression, promote cell senescence,downregulate the expression of stemness genes (Nanog, Notch1, Jag1, OCT4) and functional genes (Aggrecan, Collagen II), and upregulate the expression of the P16INK4A and Rb genes. The transfection results showed that after knocking down P16INK4A gene, hypotonic or hypertonicity had no effect on expression of genes (Aggrecan, Collagen II,Rb).

Conclusion: The change in osmotic pressure has an important effect on the biological activity of NPMSCs, and this effect may occur through the $\mathrm{p} 16^{\mathrm{INK} 4 \mathrm{~A}} / \mathrm{Rb}$ pathway. This study provides a theoretical basis for the future treatment of intervertebral disc degeneration.

\section{Introduction}

Low back pain is common, and its prevalence is increasing due to the aging of the population, serious affecting the lives and health of patients. This condition is a major burden on society because of its high medical and financial costs[1,2]. Studies have shown that intervertebral disc degeneration (IVDD) is an important pathological factor in back pain[3, 4]. The mechanism underlying this condition is relatively complex, but to date, the pathogenesis of IVDD has not been fully elucidated. Degeneration of the intervertebral disc is characterized by damage to nucleus pulposus (NP) cell function and reduced cell 
number, which in turn inhibits the synthesis of extracellular matrix $[5,6]$. The intervertebral disc connects two adjacent vertebral bodies, and no blood vessels directly supply nutrients. This structure is composed of three parts: annulus fibrosus, NP and cartilage endplate[7]. The NP is located in the center of the intervertebral disc and has a unique biological environment, which is characterized by hyperosmolarity, nutrient deficiency, acidity and hypoxia[8]. Normal intervertebral discs lack blood vessels and a nutrient supply, and metabolites are mainly eliminated through the diffusion of the cartilage endplate pathway[9] because in a hypoxic environment, cells primarily provide energy through glycolytic metabolism[10, 11]. As the degree of IVDD increases, the microenvironment of the cells in the intervertebral disc will change, the glucose supply will decrease, the oxygen supply will change, acidity will increase, and osmotic pressure will also change. These changes further aggravate IVDD and form a vicious cycle[12].

Studies have shown that NP cell damage is an important cause of IVDD[13]. Therefore, current research on the treatment of IVDD is mainly focused on preventing the degradation of the extracellular matrix and increasing the number of NP cells[14]. Blanco et al.[15] identified NP-derived mesenchymal stem cells (NPMSCs) in human degenerated NP tissues; these cells could replicate and undergo adipogenesis, osteogenesis and chondrogenesis, indicating they are potential candidates for cell therapy in IVDD. Stimulating the regeneration and repair of endogenous NPMSCs may be a new strategy for the treatment of IVDD. However, due to the complex microenvironment of the intervertebral disc, regeneration and repair of NPMSCs is difficult.

The NP tissue of the intervertebral disc contains a high level of hydrophilic extracellular matrix, and the main component is proteoglycan[16]. Aggrecan increases intervertebral disc tissue permeability and resistance to pressure, and degradation of aggrecan can lead to damage to intervertebral disc function and the occurrence of IVDD. Aggrecan plays an important role in maintaining the hydration state and osmolarity of intervertebral discs[17]. Sulfated glycosaminoglycan is highly negatively charged and adsorbs cations and water molecules, thereby increasing the osmolarity of the tissue, promoting water entry in the intervertebral disc tissue and then increasing the expansion pressure of the tissue to bear the compressive stress load of the spine[18, 19]. The various movements and loads of the spine throughout the day lead to dynamic changes in the osmolarity of the NP tissue. When the load stress exceeds the osmolarity of the NP tissue, water is squeezed out of the NP, and the osmolarity increases. When the stress is reduced, water is reabsorbed in the NP tissue to reduce osmolarity; thus, the osmolarity in the NP tissue is dynamically changing[20,21].

Studies have determined that the osmolarity of NP tissue is $430-496 \mathrm{mOsm} / \mathrm{kg} \mathrm{H}_{2} \mathrm{O}[22,23]$, which is much higher than that of other tissues. As an important factor for survival in the intervertebral disc tissue, osmolarity has a major effect on the activity of NPMSCs. Current research on the effect of osmotic pressure on NPMSCs mostly focuses on the intervertebral discs of cattle, mice, dogs, etc. In this study, for the first time, human normal NPMSCs were used to study the effect of changes in osmolarity on their biological activities and to explore the role of osmolarity in IVDD.

\section{Materials And Methods}




\section{Cell isolation and culture}

All experiments in this study were approved by the Ethics Committee of the First Affiliated Hospital of Anhui Medical University. In this study, intervertebral disc samples were collected from patients undergoing lumbar fracture surgery at the First Affiliated Hospital of Anhui Medical University. According to the Pfirrmann disc degeneration grading system, the patients with disc degeneration were classified as Grade I or Grade II. Under sterile conditions, the tissue cultured in vitro from the annulus fibrosus was carefully separated using a microscope. Then, scissors were used to cut the NP tissue into pieces, and the tissue was placed in a cell incubator and digested with $0.2 \mathrm{mg} / \mathrm{ml}$ collagenase II (Gibco, USA) for 4 to 6 hours. The supernatant was centrifuged at $1500 \mathrm{rpm}$ for $5 \mathrm{~min}$ and discarded. The centrifuged tissue was cultivated with the prepared medium, which consisted of Dulbecco's modified Eagle's medium-low glucose (HyClone, USA), 10\% fetal calf serum (Gibco, USA), and 1\% penicillin/streptomycin (Gibco, USA) at $37^{\circ} \mathrm{C}$ in $5 \% \mathrm{CO}_{2}$. After $24-48$ hours, the cells began to adhere to the wall and underwent the first fluid change, followed by a change of medium every 3 days. When the cell confluence reached approximately $90 \%$, the cells were subcultured at 1:3, and the third generation of cells was selected for the experiments.

\section{Immunophenotype of NPMSCs}

After trypsin (Biosharp, USA) digestion of NPMSCs, the cells were washed with phosphate-buffered saline (PBS, Sigma, USA) and centrifuged to generate a $100 \mu \mathrm{l}$ cell suspension. CD105-PE, CD90-PE, CD73-PE, CD45-PE, CD34-PE, and HLA-DR-PE (eBioscience, USA) monoclonal antibodies were added to each tube. The samples were incubated in the dark for $30 \mathrm{~min}$. After the cells were washed with PBS, they were resuspended in $400 \mu \mathrm{l}$ of PBS, and then, flow cytometry (BD, USA) was used to detect the percentage of positive cells and the fluorescence intensity. An isotype control (eBioscience, USA) was used for each tube.

\section{Multilineage differentiation}

The isolated cells were plated in a 6-well plate and then cultured with mesenchymal stem cell differentiation medium (Cyagen Biosciences, Guangzhou, China), including osteogenic differentiation, adipogenic differentiation, and chondrogenic differentiation media. The cells were cultured for 21 days for osteogenic differentiation, 28 days for adipogenic differentiation, and 28 days for chondrogenic differentiation. Then, the culture medium was discarded, and the cells were stained with Alizarin Red, Oil Red $\mathrm{O}$, and Alcian blue. Finally, the staining results were observed under an inverted microscope.

\section{Preparation of four experimental groups}

Cells isolated from the intervertebral disc tissue were cultured and passaged.Sterilized $\mathrm{NaCl}$ and deionized water were added to the medium to prepare culture medium with different osmotic pressure levels, and the osmotic pressure was monitored using a freezing point osmotic pressure instrument (Fiske, USA). Media with four osmotic pressure levels, namely, $250 \mathrm{mOsm} / \mathrm{kg} \mathrm{H}_{2} \mathrm{O}$ (group 1), 300 $\mathrm{mOsm} / \mathrm{kg} \mathrm{H}_{2} \mathrm{O}$ (group 2), $450 \mathrm{mOsm} / \mathrm{kg} \mathrm{H}_{2} \mathrm{O}$ (group 3) and $600 \mathrm{mOsm} / \mathrm{kg} \mathrm{H}_{2} \mathrm{O}$ (group 4), were used. Only osmotic pressure was different in each group; the other culture conditions were the same. 


\section{Cell proliferation assay}

Cell Counting Kit-8 (CCK-8) assays were used to detect the proliferation of the NPMSCs cultured under different osmotic pressure conditions. NPMSCs were seeded in 96 -well plates at a density of $5 \times 10^{3}$ cells $/ \mathrm{ml}$. These cells were cultured for $1,3,5,7,9$ and 11 days in the four groups (1, 2, 3 and 4$)$. The cells were incubated with $10 \mu \mathrm{l}$ of CCK-8 reagent (Dojindo, Japan) at $37^{\circ} \mathrm{C}$ in the dark for 2.5 hours. No cells were added to the isotype group. A SpectraMAX microplate reader was used to measure the absorbance of different groups at $450 \mathrm{~nm}$.

\section{Apoptosis assay}

The isolated cells were planted in 6-well plate. These cells were cultured in four groups (1, 2, 3 and 4) for 5 days in different osmotic media. The cells were digested with trypsin without EDTA (Biosharp, USA) and washed twice with PBS. The harvested cells were incubated with $5 \mu \mathrm{l}$ of Annexin V-FITC and $5 \mu \mathrm{l}$ of propidium iodide (PI; KeyGEN BioTECH, China) for 5 min at $37^{\circ} \mathrm{C}$ in the dark. Flow cytometry (BD, USA) was used to detect the percentage of apoptotic cells.

\section{Cell cycle analysis}

PI (Beyotime, China) staining was used to analyze the cell cycle. Briefly, after NP cells were treated with medium with different osmolarities for 5 days, they were digested with $0.25 \%$ trypsin and fixed with cold ethanol overnight. The cells were washed with PBS to remove ethanol. The prepared $500 \mu \mathrm{l} \mathrm{PI} / \mathrm{RNase} \mathrm{A}$ staining working solution was added to the tube and incubated for $30 \mathrm{~min}$ in the dark at room temperature. After the cells were washed with PBS, the fractions of each phase of the cell cycle were detected by flow cytometry.

\section{SA- $\beta$-Gal staining assay}

The cells were seeded in a 6-well plate and then cultured in the above four different osmotic pressure groups for 5 days. SA- $\beta$-Gal staining was performed according to the manufacturer's instructions (Beyotime, China). Then, the staining results were observed under an inverted microscope. Senescent cells were stained. The percentage of positive cells to the total number of cells was determined.

\section{Real-time PCR analysis}

The cells were cultured for 7 days with the above four types of media with different osmotic pressures. Then, TRIzol reagent was used to extract total RNA. Total RNA was reverse transcribed into cDNA using a reverse transcription reagent (TaKaRa, Japan). GAPDH was used as an internal reference gene. A SYBR Premix Ex Taq PCR kit (TaKaRa, Japan) and LightCycler system (Roche, Switzerland) were used to analyze the obtained cDNA for real-time quantitative PCR (RT-qPCR). The primers used for RT-qPCR are listed in Table 1 and were synthesized by Sangon Biotech (Shanghai, China). The mRNA expression of target genes was calculated with the $2^{-\Delta \Delta \mathrm{Ct}}$ method.

\section{Western blot analysis}


After 7 days of culture with media with different osmotic pressures, the four groups of cells were treated with RIPA lysis buffer (Beyotime, China), and total protein was extracted. The extracted protein samples from each group were separated by SDS-PAGE and transferred to PVDF membranes.The PVDF membranes were incubated with primary antibodies ( $\beta$-actin: Bioworld, BS6007M; Aggrecan: Abcam, ab3778; Collagen II: Abcam, ab188570; P16INK4A: Abcam, ab108349; Rb: Abcam, ab181616) and horseradish peroxidase (HRP)-conjugated secondary antibodies (Beyotime, China). After the protein bands were visualized using an ECL Plus system (Thermo, USA), their gray values were measured by Quantity One software (Bio-Rad, USA). The protein expression of target molecules was normalized to that of $\beta$-actin.

\section{P16 ${ }^{\text {INK4A }}$ knockdown by small interfering RNA (siRNA)}

The siRNA was designed and provided by GenePharma; we assessed three sequences to identify the most effective siRNA. The sequences are as follows: P16 INK4A -527 (5'-3' CGGGAAACUUAGAUCAUCATT, UGAUGAUCUAAGUUUCCCGTT), P16 INK4A -927 (5'-3'

GCAGAACCAAAGCUCAAAUTT,AUUUGAGCUUUGGUUCUGCTT) and P16 INK4A-676 (5'-3'

CCGUAAAUGUCCAUUUAUATT, UAUAAAUGGACAUUUACGGTT). First, we screened for the most effective sequence, and we grew cells in 6 wells. When the cell confluence reached approximately $80 \%$, according to the kit instructions for $\mathrm{P} 16^{\text {INK4A }}$ siRNA transfection, we cultured the cells in a $37^{\circ} \mathrm{C}$ incubator and replaced the complete medium after 6 hours. Forty-eight hours later, we assessed the P16 $6^{\text {INK4A }}$ mRNA expression, and after 72 hours, the P16 ${ }^{\text {INK4A }}$ protein expression was determined. The most effective sequence was selected for subsequent tests. After selecting the most effective sequence, we transfected it according to the instructions. Then, we incubated the samples in a $37^{\circ} \mathrm{C}$ cell incubator for 6 hours and replaced the medium with 4 types of medium with different osmotic pressure levels. The mRNA expression of related genes was detected after 48 hours, and the expression of target proteins was detected after 72 hours.

\section{Statistical analysis}

All data in this study are expressed as the mean \pm standard error of three independent replicates. The significant difference between groups was analyzed by one-way analysis of variance (ANOVA) using SPSS 19.0 software. A $P$ value $<0.05$ was considered statistically significant.

\section{Results}

\section{Isolation and characterization of NPMSCs}

After the primary cells were cultured for 4 to 5 days, the isolated and cultured cells adhered to the wall. Under a microscope, the cells adhered to the wall and had a spindle shape. The cells fused in approximately 20 days, and the speed of fusion increased after passaging. The cell morphology of the P2 and P3 generations remained uniform, and the cells had a spindle shape (Fig. 1). Flow cytometric analysis showed that the cells had high expression of CD73, CD90, and CD105 and low expression of 
CD34, CD45, and HLA-DR (Fig. 2). After 21 days of osteogenic differentiation, mineralized nodules could be detected by Alizarin Red staining. After 28 days of adipogenic differentiation, Oil Red 0 staining showed that lipid vesicles were produced in the cells. After 28 days of chondrogenic differentiation, Alcian blue staining showed the presence of sulfated proteoglycan in the cells (Fig. 3).

\section{NPMSCs cultured under different osmotic pressures}

We cultured NPMSCs in four groups under different osmotic pressures. After five days of culture, morphological changes in the cells were observed, and their morphology was recorded by photographs. As the osmotic pressure changed, the cell morphology also changed. Compared with the iso-osmotic pressure group, the hypertonic group had larger and flatter cells, and the greater the increase in osmotic pressure, the more significant the changes in the cells were. The morphology of the cells in the hypotonic group also showed the same change (Fig. 4).

\section{Cell proliferation of NPMSCs}

After the cells in the four groups (1, 2, 3, and 4) were grown for 5 days, the proliferation rate of group 1 was lower than that of group 2, and the cell proliferation rates of groups 3 and 4 decreased and were lower than that of group 2. The cell proliferation rate of group 4 was lower than that of group 3 (Fig. 5).

\section{Apoptosis assay of NPMSCs}

The cells were cultured in four groups, $1,2,3$, and 4, for 5 days. The apoptosis rate of group 2 was the lowest. The apoptotic rates of groups 1,3 and 4 were significantly higher than that of group 2 . The apoptosis rate of group 4 was higher than that of group 3 (Fig. 6).

\section{The cell cycle of NPMSCs}

We cultured the above 4 groups of cells for 5 days. The results showed that compared with the isotonic pressure group, the hypotonic group and the hypertonic group showed inhibition of the cell cycle, and the higher the osmotic pressure, the more obvious the inhibitory effect on the cells was (Fig. 7).

\section{SA- $\beta-$-Gal activity of NPMSCs}

The SA- $\beta-G a l$ activity of the hypotonic group and the hypertonic group was significantly higher than that of the isotonic group. Both hypotonic and hypertonic conditions can promote cell senescence. The greater the osmotic pressure, the more significant the enhancement of cell senescence was (Fig. 8).

\section{Gene expression of NPMSCs}

NPMSCs were cultured under four different osmotic pressures for 7 days. Compared with that in group 2, the expression of stemness genes (Nanog, Notch1, Jag1, OCT4) and functional genes (Collagen II, Aggrecan) was downregulated in group 1, group 3 and group 4, and the expression in group 4 showed greater downregulation than that of group 3. The expression of the P16 ${ }^{\text {INK4A }}$ and RB genes was also upregulated, and group 4 showed greater upregulation than group 3 (Fig. 9).

\section{Protein expression of NPMSCs}


NPMSCs were cultured in groups 1, 2, 3 and 4 for 7 days, and Western blotting results showed that compared with that in group 2, the expression of Collagen II and Aggrecan in group 1, group 3 and group 4 was downregulated, and group 4 showed greater downregulation than group 3 . The expression of P16 ${ }^{\text {INK4A }}$ and RB was also upregulated, and group 4 showed greater upregulation than group 3 (Fig. 10).

\section{The effect of P16 ${ }^{\text {INK4A }}$ knockdown on the NPMSC activity}

After knockdown of P16 ${ }^{\text {INK4A }}$ by siRNA transfection, the effects were verified by PCR and Western blots, which showed that the expression of P16 ${ }^{\text {INK4A }}$ was significantly lower than that of the control group(Fig. 11).

. After knocking down P16 ${ }^{\text {INK4A }}$, we continued to culture the cells under the above 4 osmotic pressure conditions and then tested them. The mRNA and protein levels of Collagen II, Aggrecan and RB were detected, and the results showed no significant differences among the groups (Fig. 12).

\section{Discussion}

The intervertebral disc is a tissue with a special structure. Its biological environment is relatively closed, and blood vessels that directly supply nutrients are lacking, which results in this specific structure. As the degree of IVDD increases, the microenvironment of the intervertebral disc changes, and the osmotic pressure also changes[24]. Moreover, various movements and loads of the spine lead to changes in the osmotic pressure in the NP tissue. A study by Urban et al.[25] showed that the osmotic pressure of NP tissue is between 450 and550 mOsm/ $\mathrm{kg} \mathrm{H}_{2} \mathrm{O}$ in a day. However, the exact mechanism of the effect of osmotic pressure changes on NPMSCs is still unclear. This study simulated different osmotic pressure environments to culture human normal NPMSCs from intervertebral discs to study the effect of osmotic pressure on the biological activity of these cells.

The NP tissue selected in this study was derived from patients with lumbar vertebral fractures and was from normal intervertebral discs (Pfirrmann I or II). We isolated and cultured cells in vitro and found that the cells adhered to the wall and grew in a radial spiral shape, with high expression of CD73, CD90, and CD105, low expression of HLA-DR, CD34, and CD45, and differentiation towards osteogenic, adipogenic and chondrogenic lineages. According to the evaluation criteria of the International Association for Stem Cell Therapy (ISCT)[26], the isolated and cultured cells were NPMSCs.

Ishihara et al.[27] cultivated NP tissue in vitro and found that increased osmotic pressure could enhance the synthesis of proteoglycans, and the increase in proteoglycan synthesis was related to the osmotic pressure of the culture medium but unrelated to $\mathrm{Na}^{+}$or $\mathrm{Cl}^{-}$. Neidlinger et al.[28] increased the osmotic pressure of the medium in bovine NP cells from $300 \mathrm{mOsm} / \mathrm{kg} \mathrm{H}_{2} \mathrm{O}$ to $500 \mathrm{mOsm} / \mathrm{kg} \mathrm{H}_{2} \mathrm{O}$, and the proteoglycan expression increased. Spillekom et al.[29] found that the synthesis of proteoglycan in dog $\mathrm{NP}$ cells was optimal when the osmotic pressure in the culture medium was $400 \mathrm{mOsm} / \mathrm{kg} \mathrm{H}_{2} \mathrm{O}$. Studies have also found that high osmotic pressure can inhibit the proliferation of NP cells and the synthesis of 
extracellular matrix and promote the apoptosis of NPMSCs[30-32]. The above findings on osmotic pressure on the biological activity of NP cells are different, which may be caused by the method of cell culture, the difference in cell species, and the different exposure conditions. In this study, we simulated different osmotic pressure environments in vitro and cultured NPMSC cells under different osmotic pressure conditions. Experimental results showed that compared with normal osmotic pressure, hypotonic and hypertonic environments inhibited the proliferation of NPMSCs. The higher the osmotic pressure, the more obvious the inhibition of NPMSC proliferation was.

High osmotic pressure disrupts the cell cycle, can arrest cells in the G1 phase and inhibits the cell cycle[33-35]. These findings are similar to our research results. We used flow cytometry to detect the cell cycle of the NPMSCs cultured under different osmotic pressures and found that compared with the normal osmotic pressure group, the high osmotic pressure group showed arrest of cells in the G1 phase. The higher the osmotic pressure, the stronger the inhibitory effect is. Research shows that not only high osmotic pressure but also low osmotic pressure can impair the cell cycle progression of NPMSCs. Changes in osmotic pressure also affect the expression of extracellular matrix. The results showed that when the osmotic pressure was decreased or increased, the expression of related genes (Nanog, Nocth1, Jag1, OCT4) in NPMSCs decreased, and the expression of Collagen II and Aggrecan was also reduced compared to that in the normal osmotic pressure group. These results suggested that abnormal changes in osmotic pressure will cause dysfunction of NPMSCs, which will lead to IVDD.

Messmer[36] found that an increase in tear osmotic pressure is the main cause of ocular inflammation and corneal stem cell apoptosis and aging. Many studies have shown that as cells age, the level of $\mathrm{P} 16^{\mathrm{INK} 4 \mathrm{~A}}$ increases[37-39]. The $\mathrm{P} 16^{\mathrm{INK} 4 \mathrm{~A}} / \mathrm{Rb}$ signaling pathway plays an important role in cell senescence, and $\mathrm{P} 16^{\mathrm{INK} 4 \mathrm{~A}}$ can cause permanent cell growth arrest and cell senescence[40].

This study also confirmed these findings. Research shows that compared with the normal osmotic pressure group, the hypotonic and hypertonic groups showed an increased proportion of cell senescence, as demonstrated by galactosidase staining, the expression of the P16 ${ }^{\mathrm{INK} 4 \mathrm{~A}}$ and Rb genes increased, and the expression of Collagen II and Aggrecan decreased. These results suggested that low and high osmotic pressure induced the upregulation of P16 $6^{\text {INK4A }}$ gene expression in NPMSCs, causing damage to NPMSCs.

To further clarify the role of P16 ${ }^{\mathrm{INK} 4 \mathrm{~A}}$ and osmotic pressure in NPMSCs, we used siRNA transfection to knock down the expression of $\mathrm{P} 16^{\mathrm{INK} 4 \mathrm{~A}}$. We detected the $\mathrm{P} 16^{\mathrm{INK} 4 \mathrm{~A}}$ protein level by Western blots and the P16 ${ }^{\text {INK4A }}$ mRNA level by PCR. We found that the expression of P16 ${ }^{\text {INK4A }}$ in the siRNA-transfected cells was significantly lower than that of the control group. Both methods showed good transfection effects and high efficiency. After knockdown of P16 ${ }^{\text {INK4A }}$, we found that there was no significant difference in the expression of the Collagen II, Aggrecan and Rb genes after the osmotic pressure was changed, as shown by PCR and Western blots. Silencing of the P16 ${ }^{\text {INK4A }}$ gene blocked the adverse effects of osmotic pressure on the expression of the Collagen II, Aggrecan and RB genes in NPMSCs. 
$\mathrm{P} 16^{\text {INK4A }} / \mathrm{Rb}$ is an important pathway for cell proliferation. During normal cell proliferation, Cyclin D1 forms a complex with CDK4/6 to phosphorylate the Rb protein, and the phosphorylated $\mathrm{Rb}$ protein is dissociated from the transcription factor E2F, which promotes cell transition from $\mathrm{G} 1$ to $\mathrm{S}$ phase and enhances cell proliferation[41]. The P16 ${ }^{\mathrm{INK} 4 \mathrm{~A}}$ protein is an inhibitor of CDK4/6, which can compete with Cyclin D1 to bind CDK4/6, inhibit CDK4/6-mediated phosphorylation of RB protein, prevent cells from entering $S$ phase from $\mathrm{G} 1$ phase, and inhibit cell proliferation[41, 42]. This study confirmed that compared with the normal osmotic pressure group, the low osmotic pressure and high osmotic pressure groups showed activation of the P16 ${ }^{\text {INK4A }} /$ Rb signaling pathway. The expression of the P16 ${ }^{\text {INK4A }}$ gene was upregulated, and the phosphorylation level of the $\mathrm{Rb}$ protein was reduced. $\mathrm{Rb}$ combined with the transcription factor E2F and prevented cells from entering the $S$ phase from the $\mathrm{G} 1$ phase,and the cell cycle is inhibited. After knockdown of P16 ${ }^{\text {INK4A }}$ expression by siRNA, the P16 ${ }^{\text {INK4A }} /$ Rb signaling pathway was blocked, the change in osmotic pressure could not activate the $\mathrm{P} 16^{\mathrm{INK} 4 \mathrm{~A}} / \mathrm{Rb}$ signaling pathway, the expression of the Rb gene was not affected, and the cell cycle progression of NPMSCs was not blocked. Cell aging was inhibited, and the expression of extracellular matrix components did not decrease. Because of the time limit of siRNA transfection, we did not conduct long-term cell culture on the knockdown cells and did not perform more in-depth research on cell differentiation and proliferation.

We used fetal bovine serum instead of human serum to culture the human NPMSCs. Differences in serum species may affect the test results, but human serum samples are limited. Second, the study was conducted in 2D culture medium, and the response of NPMSCs in a 3D culture system may be different. Third, the research on the silencing of $\mathrm{P} 16^{\mathrm{INK} 4 \mathrm{~A}}$ gene is mainly carried out in monolayer cultured NPMSCs. Dedifferentiation and short-term effects are inevitable.Although these effects were biologically important, they may not be relevant to in vivo situations. The long-term effect in the body is very important. Although the exact mechanism of P16 ${ }^{\text {INK4A }}$ has yet to be determined, knocking down P16 INK4A in NP cells may have some beneficial biological functions.

\section{Conclusion}

In summary,the results showed that changes in osmotic pressure have an important effect on the biological activity of NPMSCs, hypotonic or hypertonic can induce cell apoptosis and promote cell senescence. Studies have shown that this effect may occur through the P16 1 INK4A $/ \mathrm{Rb}$ pathway and affect the regeneration and restore functions of NPMSCs.By knocking down the P16 ${ }^{\text {INK4A }}$ gene, the adverse effects of changes in osmotic pressure on cells can be reversed. This study provides a useful theoretical basis for the treatment of IVDD in the future.

\section{Abbreviations}

\section{NPMSCs}

human nucleus pulposus-derived mesenchymal stem cells IVD 
Intervertebral disc

NP

Nucleus pulpous

IVDD

Intervertebral disc degeneration

FBS

Fetal bovine serum

DMEM

Dulbecco s modified Eagle s medium

SDS-PAGE

Sodium dodecyl sulfate polyacrylamide gel electrophoresis

PVDF

Polyvinylidene difluoride

GAPDH

Glyceraldehyde-3-phosphate dehydrogenase

PBS

Phosphate-buffered saline

PE

Phycoerythrin

$\mathrm{Rb}$

Retinoblastoma

\section{Declarations}

\section{Acknowledgements[}

Not applicable.

\section{Authors' contributions}

$\mathrm{HZ}$ performed the laboratory work,writing the original draft. WL performed the laboratory work, revised this paper.YSZ and HT designed and supervised the research, revised this paper.SQZ ,JL and CLS contributed to data analysis.LTH,ZYW and HYC assisted in the data interpretation. The authors read and approved the final manuscript.

\section{Funding}

This study was supported by the National Natural Science Foundation of China (NO.82072492,81601935).

\section{Availability of data and materials}


The datasets used and/or analyzed during the current study are available from the corresponding author on reasonable request.

\section{Declarations}

\section{Ethics approval and consent to participate}

All experiments in this study were approved by the Ethics Committee of the First Affiliated Hospital of Anhui Medical University and were performed in accordance with established guidelines.

\section{Consent for publication}

Not applicable.

\section{Competing interests}

The authors declare that they have no competing interests.

\section{Author details}

${ }^{1}$ Department of Orthopedics, the First Affiliated Hospital of Anhui Medical University,218\# Jixi Road, Hefei, 230022, Anhui,China

${ }^{2}$ Department of Biochemistry and Molecular,Anhui Medical University $₫ 81 \#$ Meishan Road, Hefei, 230022, Anhui,China

${ }^{3}$ Department of Clinical Laboratory, the First Affiliated Hospital of Anhui Medical University,218\# Jixi Road, Hefei, 230022, Anhui,China

\section{References}

1. Wenig CM, Schmidt CO, Kohlmann T, Schweikert B. Costs of back pain in Germany. Eur J Pain. 2009;13:280-6.

2. Steffens D, Maher CG, Pereira LS, Stevens ML, Oliveira VC, Chapple M, et al. Prevention of Low Back Pain: A Systematic Review and Meta-analysis. Jama Intern Med. 2016;176:199-208.

3. Williams FM, Sambrook PN. Neck and back pain and intervertebral disc degeneration: role of occupational factors. Best Pract Res Clin Rheumatol. 2011;25:69-79.

4. Park T, Kuo A, Smith MT. Chronic low back pain: a mini-review on pharmacological management and pathophysiological insights from clinical and pre-clinical data. Inflammopharmacology. 2018.

5. Gu T, Shi Z, Wang C, Chen C, Wu J, Wang D, et al. Human bone morphogenetic protein 7 transfected nucleus pulposus cells delay the degeneration of intervertebral disc in dogs. J Orthop Res. 2017;35:1311-22. 
6. Freemont AJ, Watkins A, Le Maitre C, Jeziorska M, Hoyland JA. Current understanding of cellular and molecular events in intervertebral disc degeneration: implications for therapy. J Pathol. 2002;196:374-9.

7. Cs-Szabo G, Ragasa-San JD, Turumella V, Masuda K, Thonar EJ, An HS. Changes in mRNA and protein levels of proteoglycans of the anulus fibrosus and nucleus pulposus during intervertebral disc degeneration. Spine (Phila Pa 1976). 2002;27:2212-9.

8. Kepler CK, Ponnappan RK, Tannoury CA, Risbud MV, Anderson DG. The molecular basis of intervertebral disc degeneration. Spine J. 2013;13:318-30.

9. Malandrino A, Lacroix D, Hellmich C, Ito K, Ferguson SJ, Noailly J. The role of endplate poromechanical properties on the nutrient availability in the intervertebral disc. Osteoarthritis Cartilage. 2014;22:1053-60.

10. Bibby SR, Jones DA, Ripley RM, Urban JP. Metabolism of the intervertebral disc: effects of low levels of oxygen, glucose, and $\mathrm{pH}$ on rates of energy metabolism of bovine nucleus pulposus cells. Spine (Phila Pa 1976). 2005;30:487-96.

11. Holm S, Maroudas A, Urban JP, Selstam G, Nachemson A. Nutrition of the intervertebral disc: solute transport and metabolism. Connect Tissue Res. 1981;8:101-19.

12. Sakai D, Nakamura Y, Nakai T, Mishima T, Kato S, Grad S, et al. Exhaustion of nucleus pulposus progenitor cells with ageing and degeneration of the intervertebral disc. Nat Commun. 2012;3:1264.

13. Liu Z, Zhang Z, Zhang A, Zhang F, Du W, Zhang Y, et al. Osteogenic protein-1 alleviates high glucose microenvironment-caused degenerative changes in nucleus pulposus cells. Biosci Rep. 2019;39.

14. Smith LJ, Nerurkar NL, Choi KS, Harfe BD, Elliott DM. Degeneration and regeneration of the intervertebral disc: lessons from development. Dis Model Mech. 2011;4:31-41.

15. Blanco JF, Graciani IF, Sanchez-Guijo FM, Muntión S, Hernandez-Campo P, Santamaria C, et al. Isolation and characterization of mesenchymal stromal cells from human degenerated nucleus pulposus: comparison with bone marrow mesenchymal stromal cells from the same subjects. Spine (Phila Pa 1976). 2010;35:2259-65.

16. Urban JP, Roberts S. Degeneration of the intervertebral disc. Arthritis Res Ther. 2003;5:120-30.

17. Roughley PJ, Alini M, Antoniou J. The role of proteoglycans in aging, degeneration and repair of the intervertebral disc. Biochem Soc Trans. 2002;30:869-74.

18. Wang DL, Jiang SD, Dai LY. Biologic response of the intervertebral disc to static and dynamic compression in vitro. Spine (Phila Pa 1976). 2007;32:2521-8.

19. Erwin WM, Hood KE. The cellular and molecular biology of the intervertebral disc: A clinician's primer. J Can Chiropr Assoc. 2014;58:246-57.

20. Shirazi-Adl A. Analysis of large compression loads on lumbar spine in flexion and in torsion using a novel wrapping element. J Biomech. 2006;39:267-75.

21. McMillan DW, Garbutt G, Adams MA. Effect of sustained loading on the water content of intervertebral discs: implications for disc metabolism. Ann Rheum Dis. 1996;55:880-7. 
22. Johnson ZI, Shapiro IM, Risbud MV. Extracellular osmolarity regulates matrix homeostasis in the intervertebral disc and articular cartilage: evolving role of TonEBP. Matrix Biol. 2014;40:10-6.

23. van Dijk B, Potier E, Ito K. Culturing bovine nucleus pulposus explants by balancing medium osmolarity. Tissue Eng Part C Methods. 2011;17:1089-96.

24. Hudson KD, Alimi M, Grunert P, Härtl R, Bonassar LJ. Recent advances in biological therapies for disc degeneration: tissue engineering of the annulus fibrosus, nucleus pulposus and whole intervertebral discs. Curr Opin Biotechnol. 2013;24:872-9.

25. Urban JP. The role of the physicochemical environment in determining disc cell behaviour. Biochem Soc Trans. 2002;30:858-64.

26. Dominici M, Le Blanc K, Mueller I, Slaper-Cortenbach I, Marini F, Krause D, et al. Minimal criteria for defining multipotent mesenchymal stromal cells. The International Society for Cellular Therapy position statement. Cytotherapy. 2006;8:315-7.

27. Ishihara H, Warensjo K, Roberts S, Urban JP. Proteoglycan synthesis in the intervertebral disk nucleus: the role of extracellular osmolality. Am J Physiol. 1997;272:C1499-506.

28. Neidlinger-Wilke C, Mietsch A, Rinkler C, Wilke HJ, Ignatius A, Urban J. Interactions of environmental conditions and mechanical loads have influence on matrix turnover by nucleus pulposus cells. $\mathrm{J}$ Orthop Res. 2012;30:112-21.

29. Spillekom S, Smolders LA, Grinwis GC, Arkesteijn IT, Ito K, Meij BP, et al. Increased osmolarity and cell clustering preserve canine notochordal cell phenotype in culture. Tissue Eng Part C Methods. 2014;20:652-62.

30. Li P, Gan Y, Wang H, Xu Y, Li S, Song L, et al. Role of the ERK1/2 pathway in osmolarity effects on nucleus pulposus cell apoptosis in a disc perfusion culture. J Orthop Res. 2017;35:86-92.

31. Palacio-Mancheno PE, Evashwick-Rogler TW, Laudier DM, Purmessur D, latridis JC. Hyperosmolarity induces notochordal cell differentiation with aquaporin3 upregulation and reduced $\mathrm{N}$-cadherin expression. J Orthop Res. 2018;36:788-98.

32. Yang Y, Wang X, Liu Z, Xiao X, Hu W, Sun Z. Osteogenic protein-1 attenuates nucleus pulposus cell apoptosis through activating the PI3K/Akt/mTOR pathway in a hyperosmotic culture. Biosci Rep. 2018;38.

33. Burg MB, Ferraris JD, Dmitrieva NI. Cellular response to hyperosmotic stresses. Physiol Rev. 2007;87:1441-74.

34. Kishi H, Nakagawa K, Matsumoto M, Suga M, Ando M, Taya $Y$, et al. Osmotic shock induces G1 arrest through p53 phosphorylation at Ser33 by activated p38MAPK without phosphorylation at Ser15 and Ser20. J Biol Chem. 2001;276:39115-22.

35. Mavrogonatou E, Kletsas D. High osmolality activates the $\mathrm{G} 1$ and $\mathrm{G} 2$ cell cycle checkpoints and affects the DNA integrity of nucleus pulposus intervertebral disc cells triggering an enhanced DNA repair response. DNA Repair (Amst). 2009;8:930-43.

36. Messmer EM, Bulgen M, Kampik A. Hyperosmolarity of the tear film in dry eye syndrome. Dev Ophthalmol. 2010;45:129-38. 
37. Janzen V, Forkert R, Fleming HE, Saito Y, Waring MT, Dombkowski DM, et al. Stem-cell ageing modified by the cyclin-dependent kinase inhibitor p16INK4a. Nature. 2006;443:421-6.

38. Krishnamurthy J, Ramsey MR, Ligon KL, Torrice C, Koh A, Bonner-Weir S, et al. p16INK4a induces an age-dependent decline in islet regenerative potential. Nature. 2006;443:453-7.

39. Molofsky AV, Slutsky SG, Joseph NM, He S, Pardal R, Krishnamurthy J, et al. Increasing p16INK4a expression decreases forebrain progenitors and neurogenesis during ageing. Nature. 2006;443:44852.

40. Sherr CJ, Roberts JM. CDK inhibitors: positive and negative regulators of G1-phase progression. Genes Dev. 1999;13:1501-12.

41. Trimarchi JM, Fairchild B, Wen J, Lees JA. The E2F6 transcription factor is a component of the mammalian Bmi1-containing polycomb complex. Proc Natl Acad Sci U S A. 2001;98:1519-24.

42. Silva J, Silva JM, Domínguez G, García JM, Cantos B, Rodríguez R, et al. Concomitant expression of p16INK4a and p14ARF in primary breast cancer and analysis of inactivation mechanisms. J Pathol. 2003;199:289-97.

\section{Tables}

\section{Table 1. Primers of Target Genes}

\begin{tabular}{|lll|}
\hline Gene & Forward $\left(5^{\prime}\right.$-3 $\left.^{\prime}\right)$ & Reverse $\left(5^{\prime}\right.$-3' $\left.^{\prime}\right)$ \\
\hline GAPDH & GGAGCGAGATCCCTCCAAAAT & GGCTGTTGTCATACTTCTCATGG \\
\hline Nanog & GCTTTGAAGCATCCGACTGT & TTTGGGACTGGTGGAAGAAT \\
\hline Notch1 & GCCTCAACATCCCCTACAAG & CACGAAGAACAGAAGCACAAA \\
\hline Jag1 & GGGTCACTGTCAGAATGAAATC & AGTCACTGGCACGGTTGTAG \\
\hline ocT4 & ACACTGCAGCAGATCAGCCAC & CCAGAGGAAAGGACACTGGTC \\
\hline Aggrecan & GTGCCTATCAGGACAAGGTCT & GATGCCTTTCACCACGACTTC \\
\hline Collagen II & CTTCCTACGGGGAATCTGTGT & CAATGGCGTTTTGGGTGTTC \\
\hline P16 INK4A & GGGTTTTCGTGGTTCACATCC & CTAGACGCTGGCTCCTCAGTA \\
\hline Rb & TTGGATCACAGCGATACAAACTT & AGCGCACGCCAATAAAGACAT \\
\hline
\end{tabular}

\section{Figures}




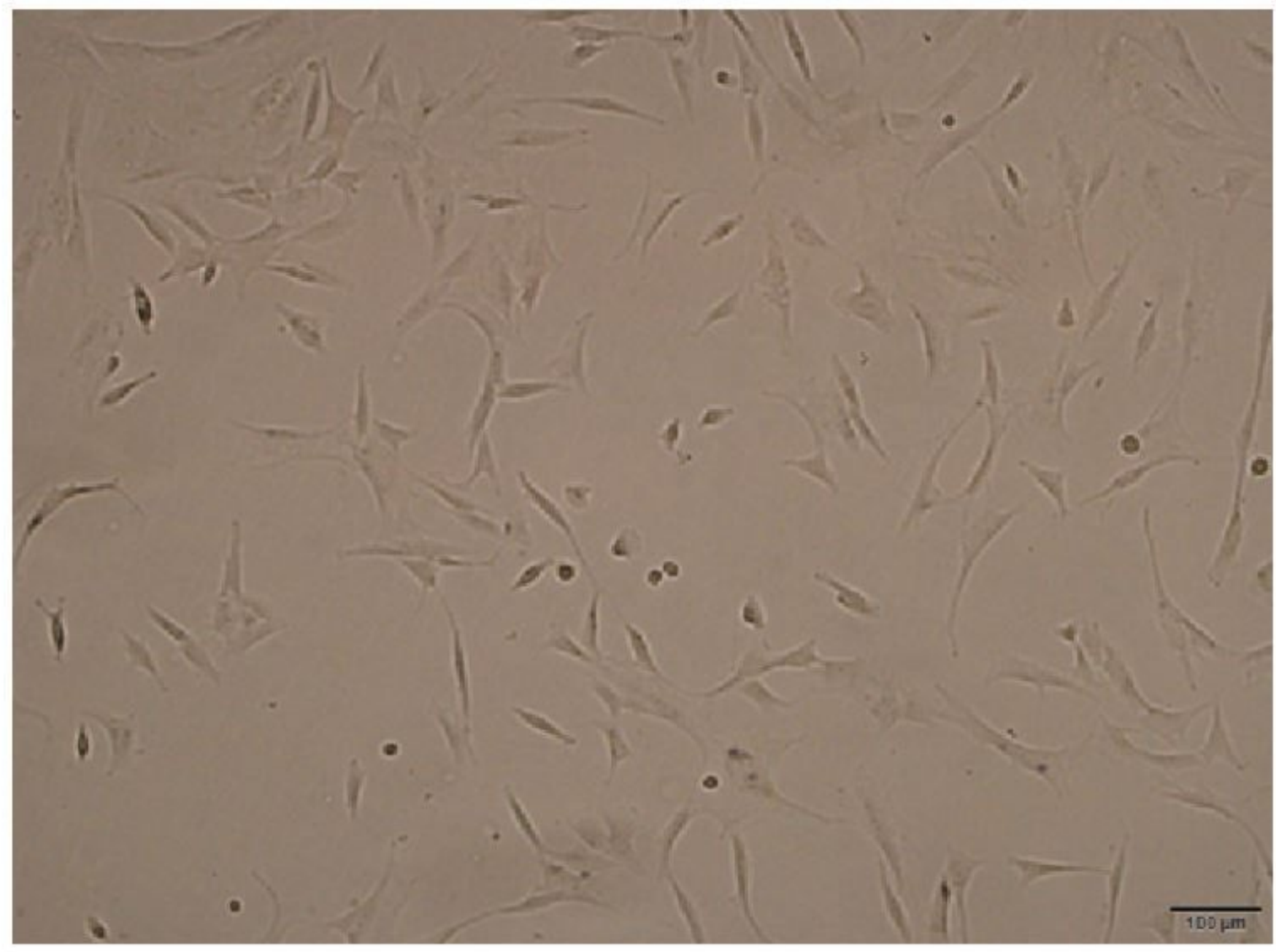

Figure 1

please see the Figure file in the Supplementary section for the full caption 

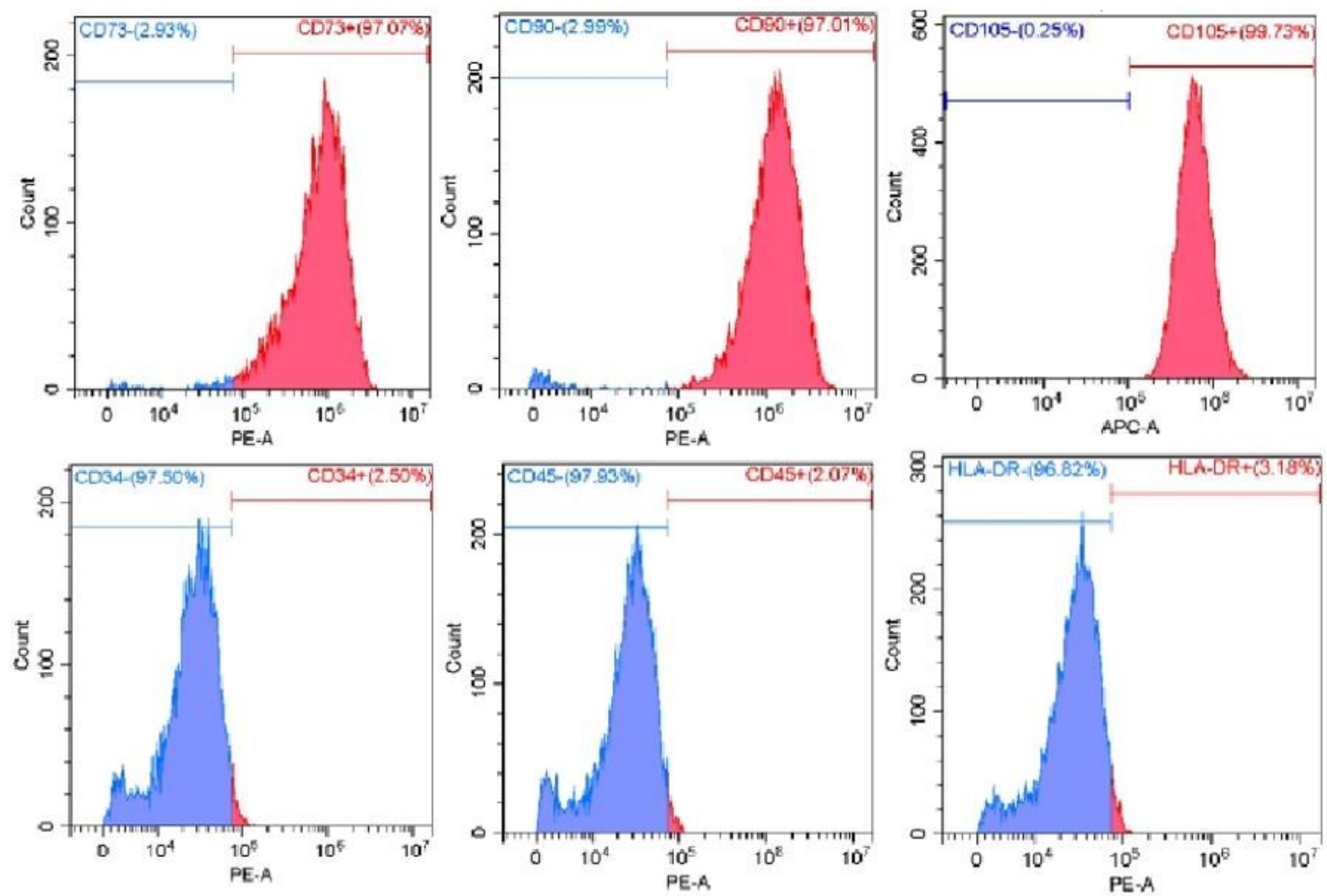

Figure 2

please see the Figure file in the Supplementary section for the full caption 

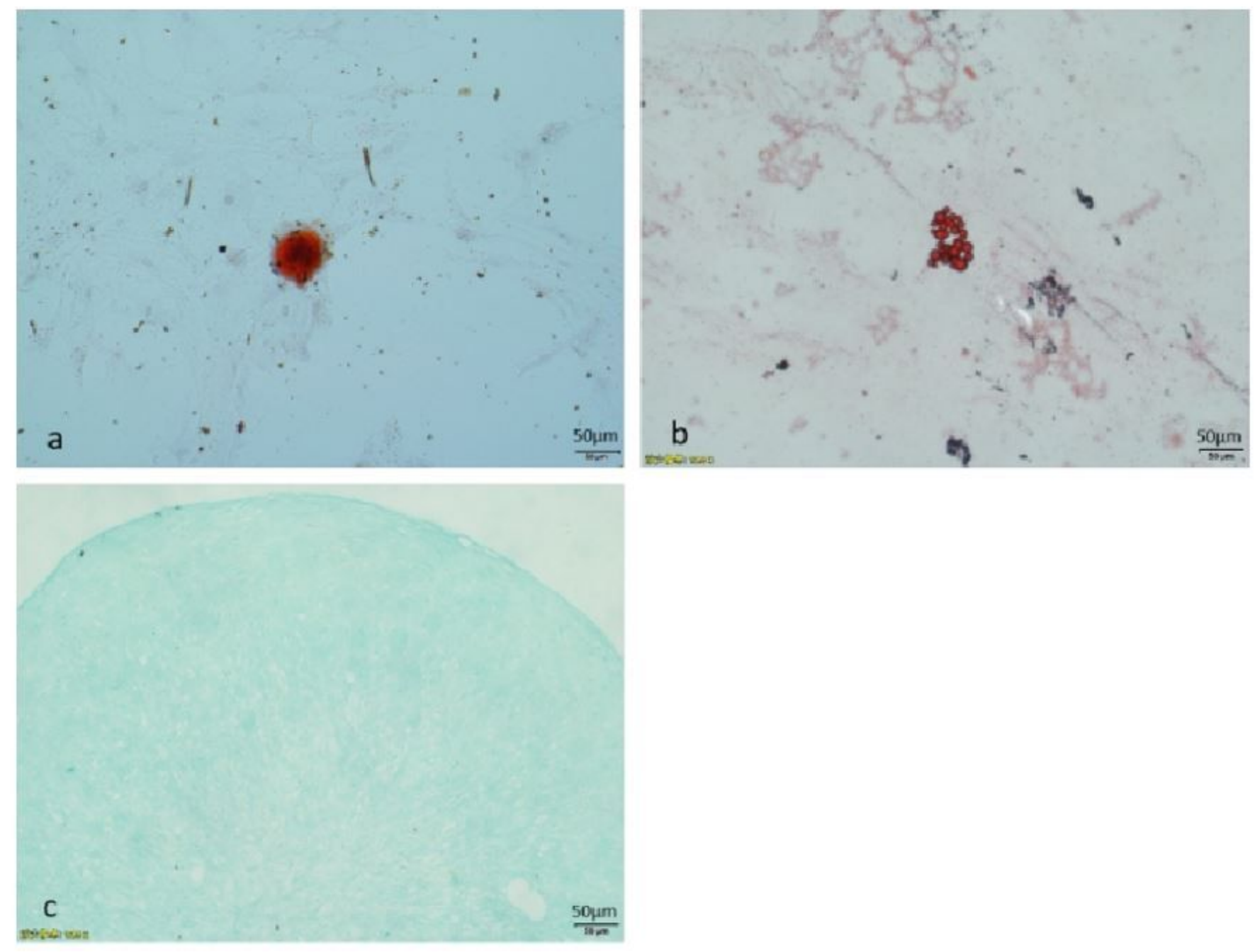

Figure 3

please see the Figure file in the Supplementary section for the full caption 

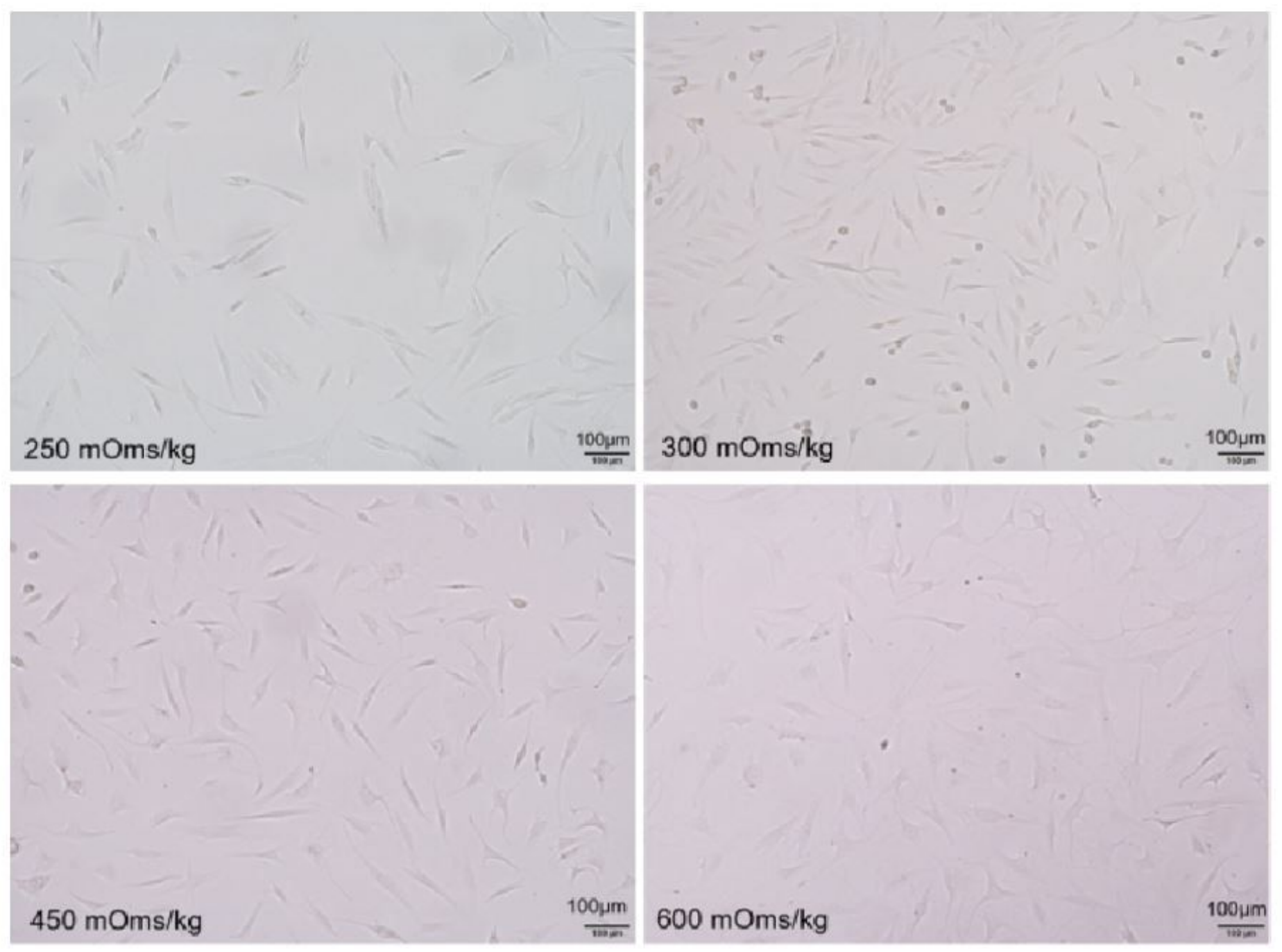

\section{Figure 4}

please see the Figure file in the Supplementary section for the full caption 


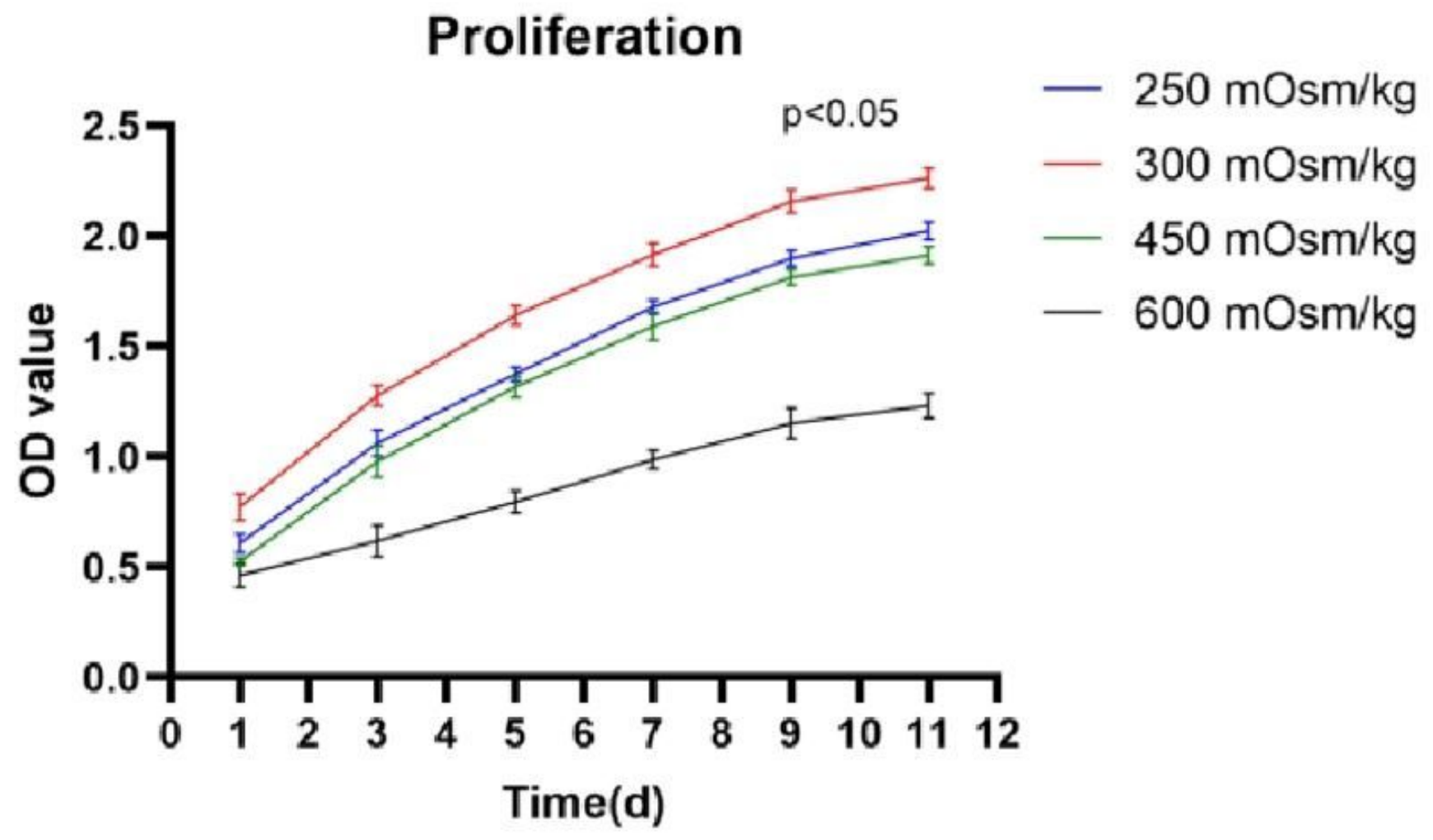

Figure 5

please see the Figure file in the Supplementary section for the full caption 


\section{Apotosis}

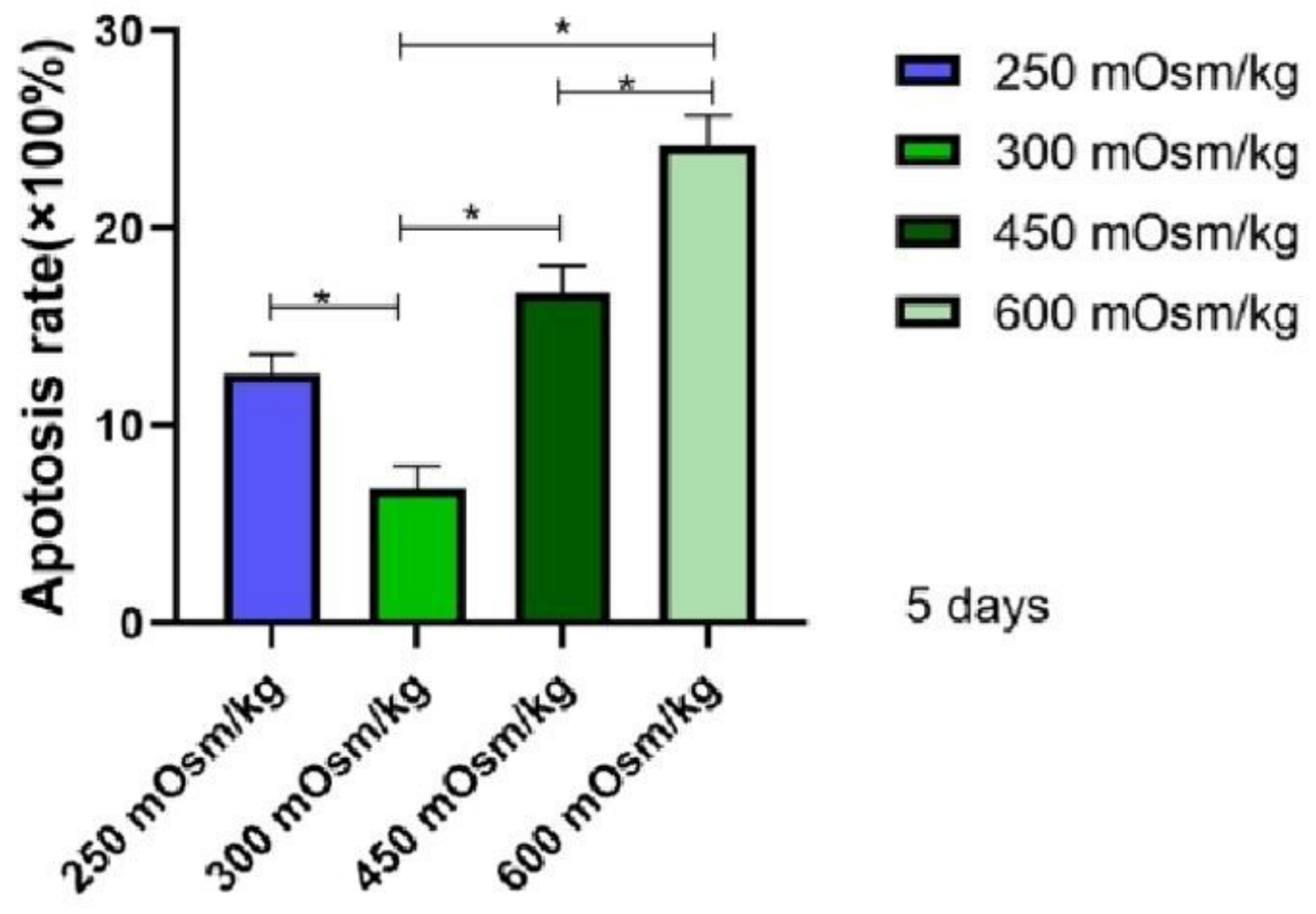

Figure 6

please see the Figure file in the Supplementary section for the full caption 


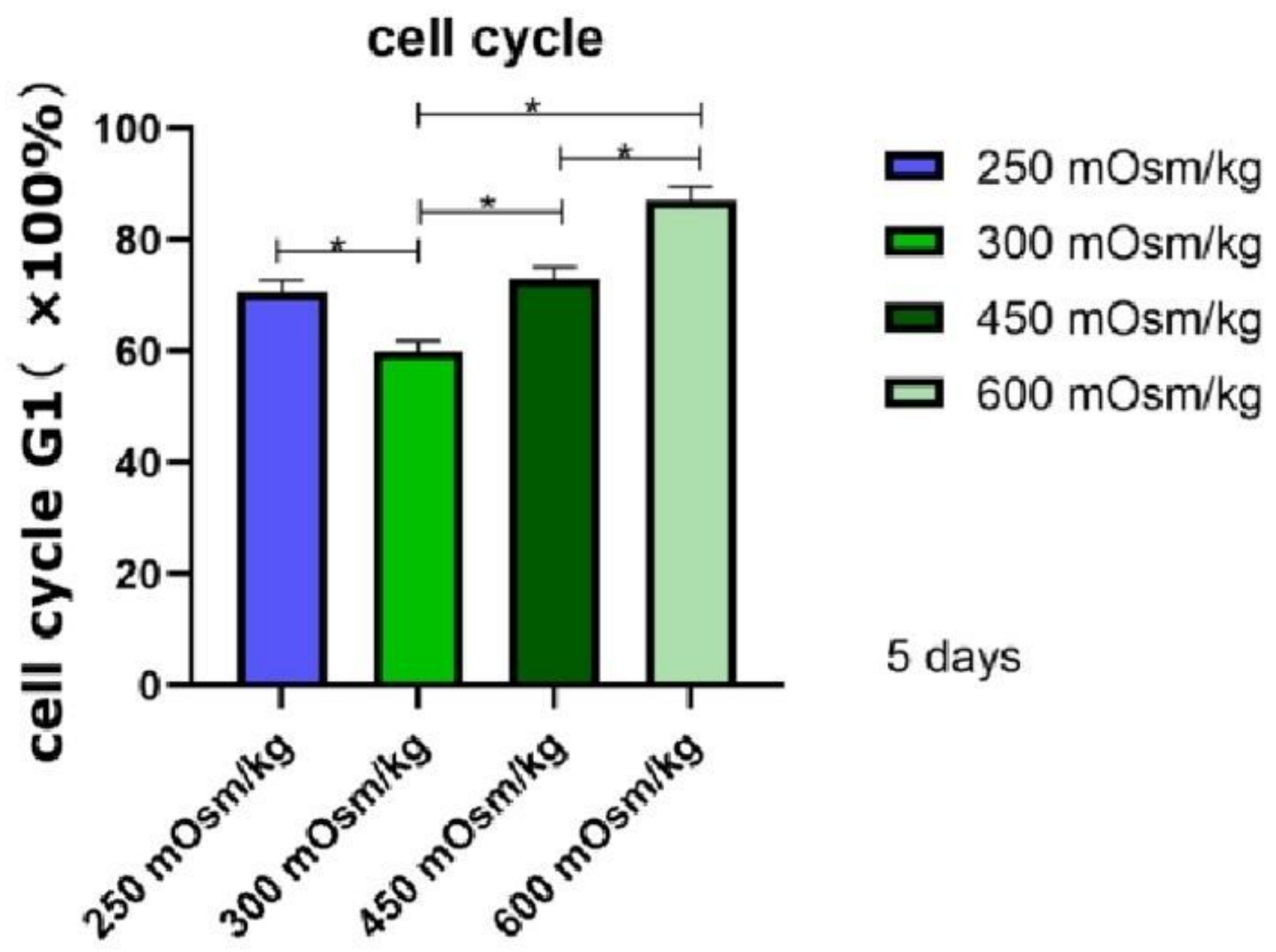

Figure 7

please see the Figure file in the Supplementary section for the full caption 
a
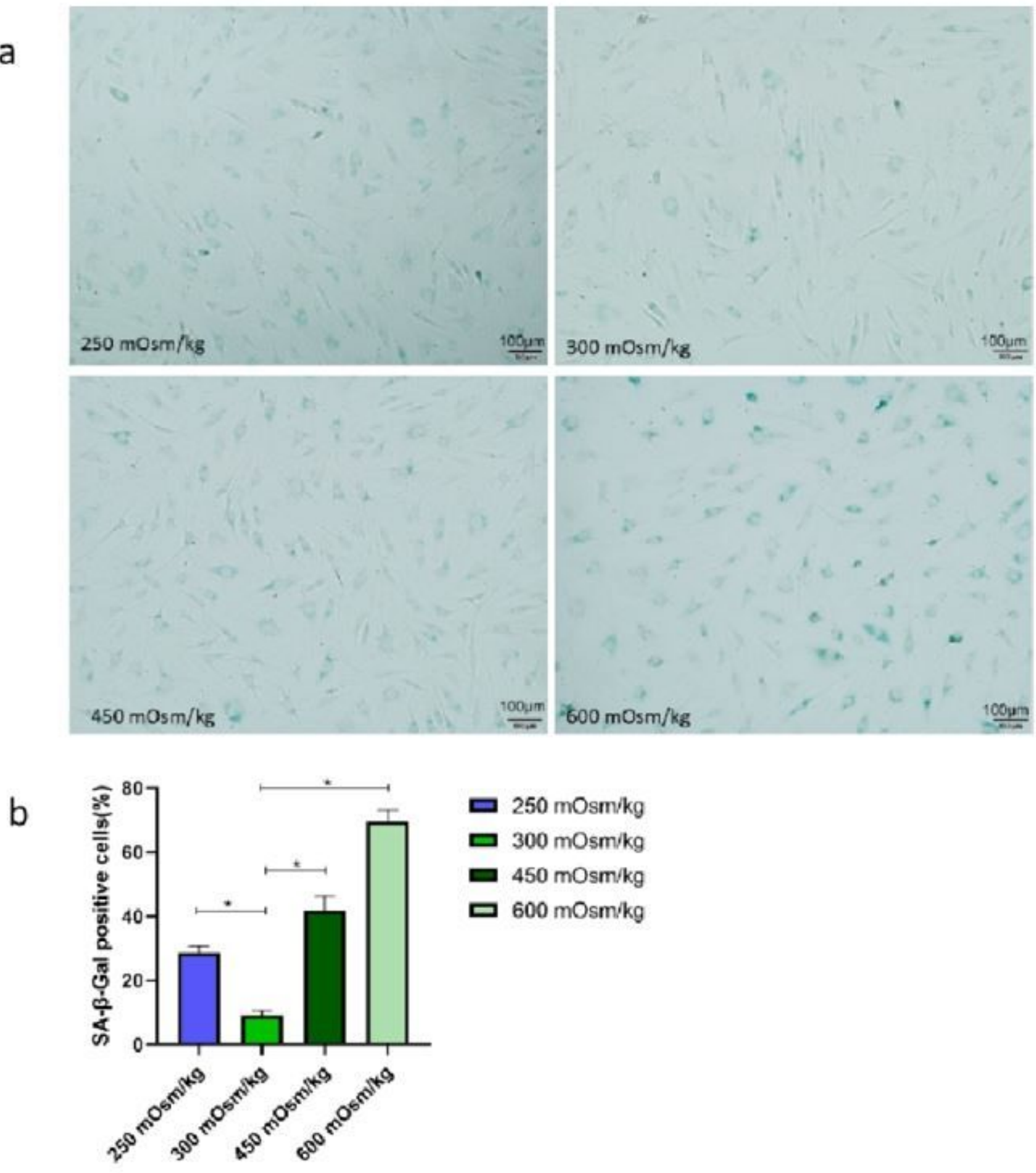

Figure 8

please see the Figure file in the Supplementary section for the full caption 

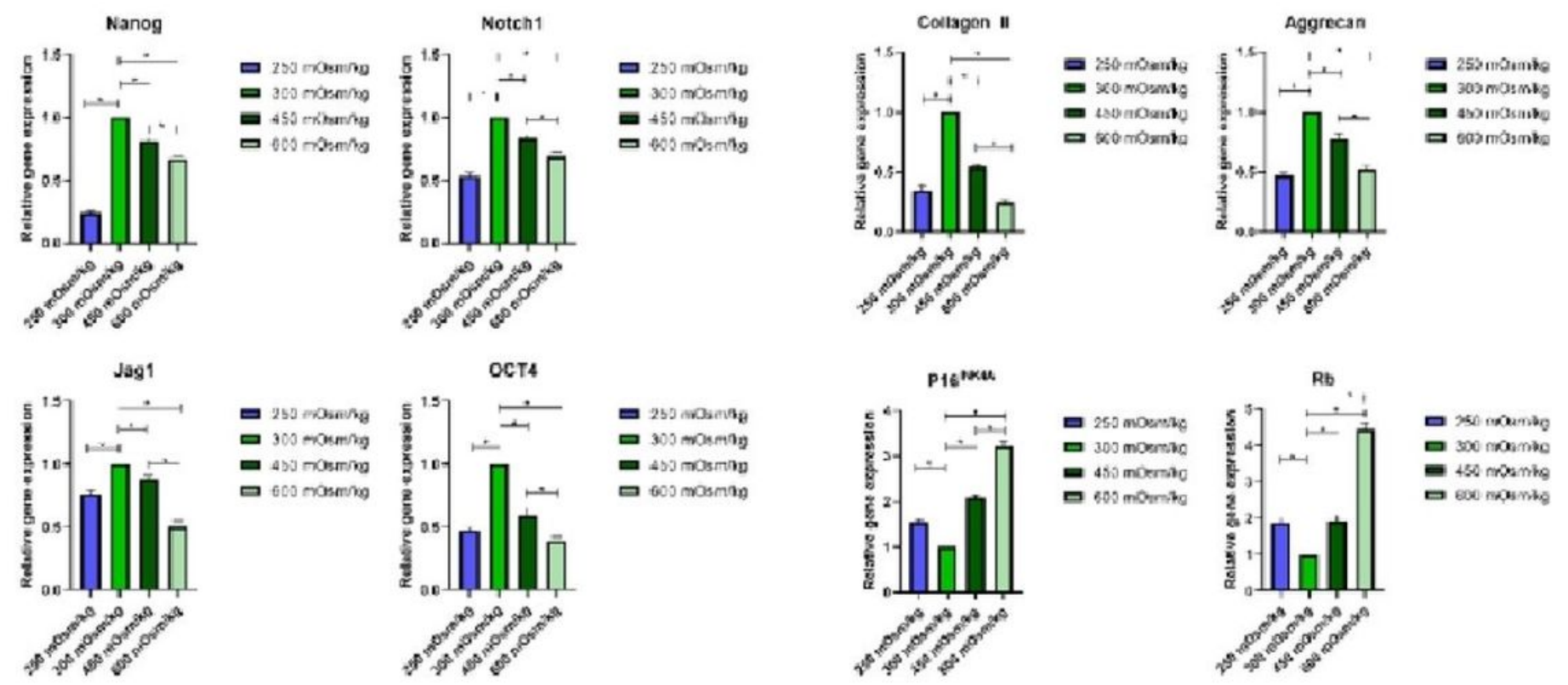

a
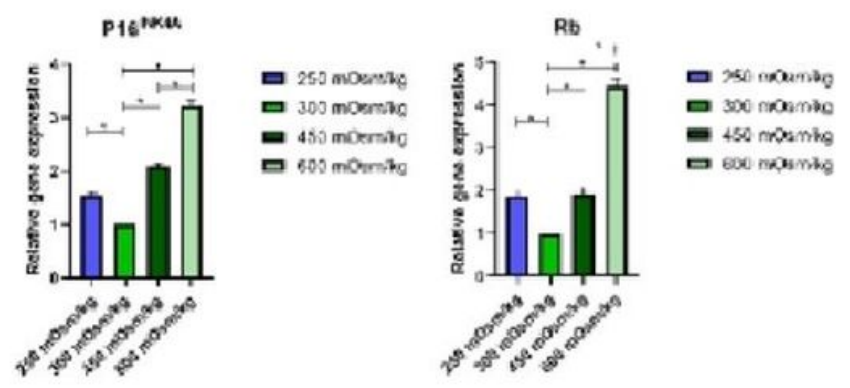

b

Figure 9

please see the Figure file in the Supplementary section for the full caption
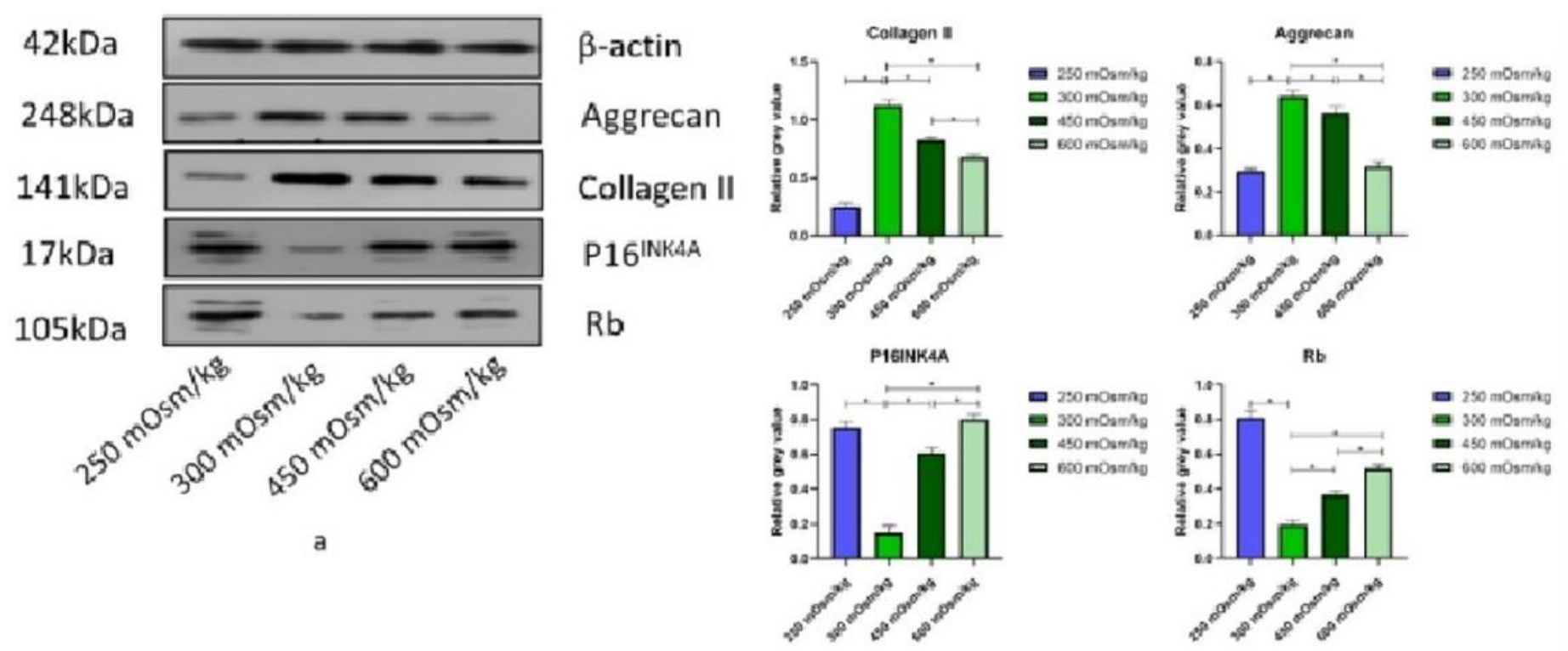

b

Figure 10

please see the Figure file in the Supplementary section for the full caption 
a

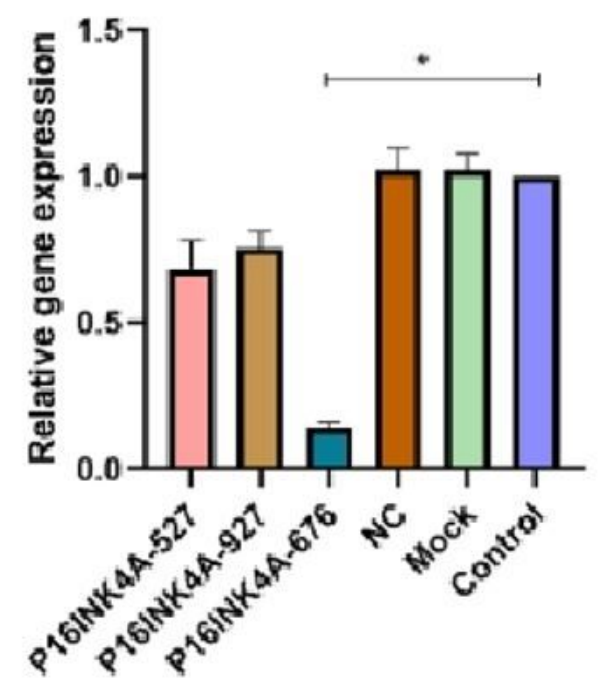

b

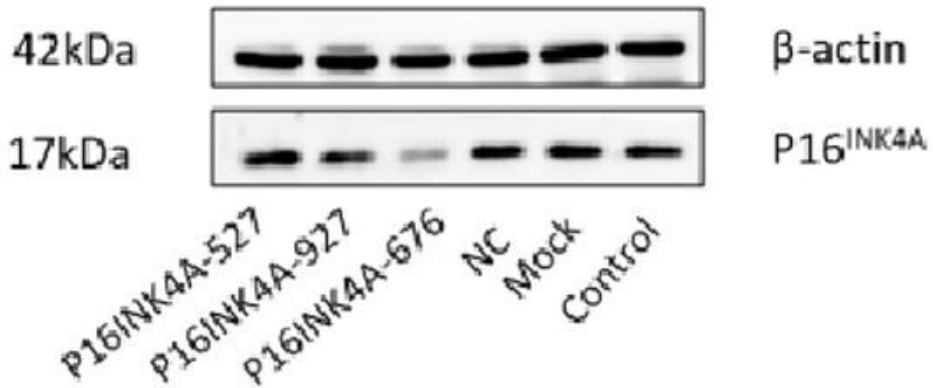

Figure 11

please see the Figure file in the Supplementary section for the full caption 


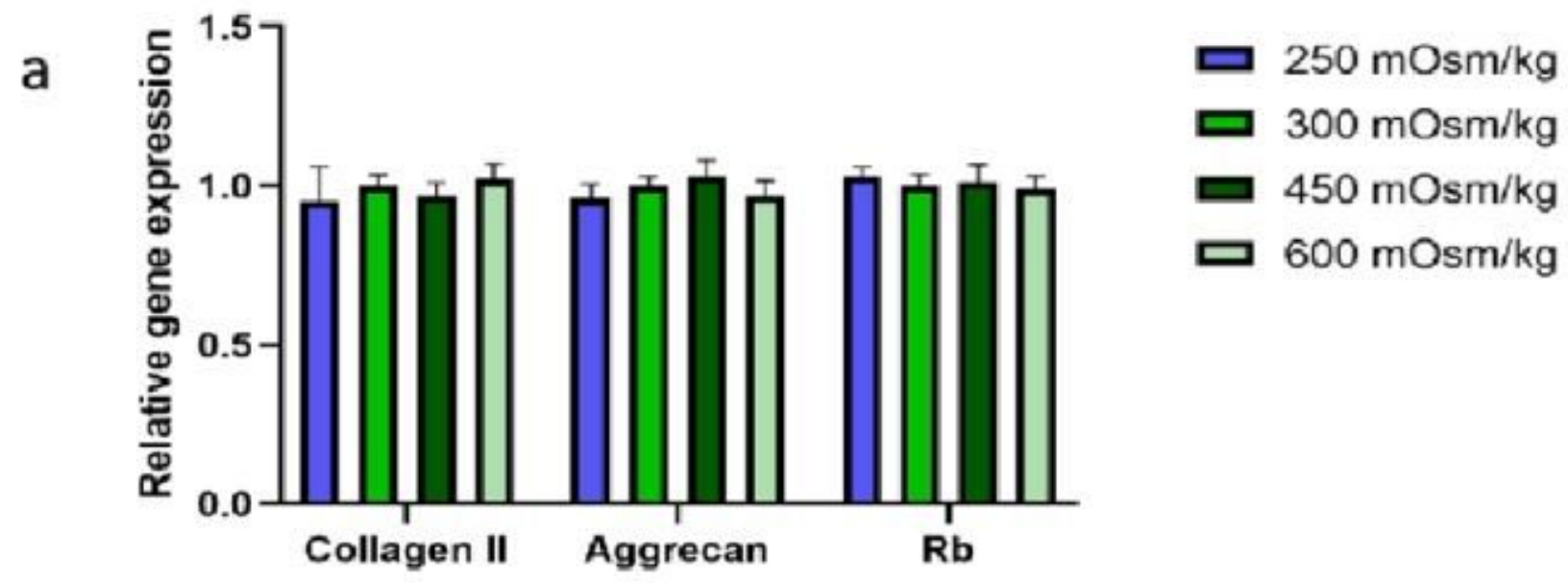

Collagen II

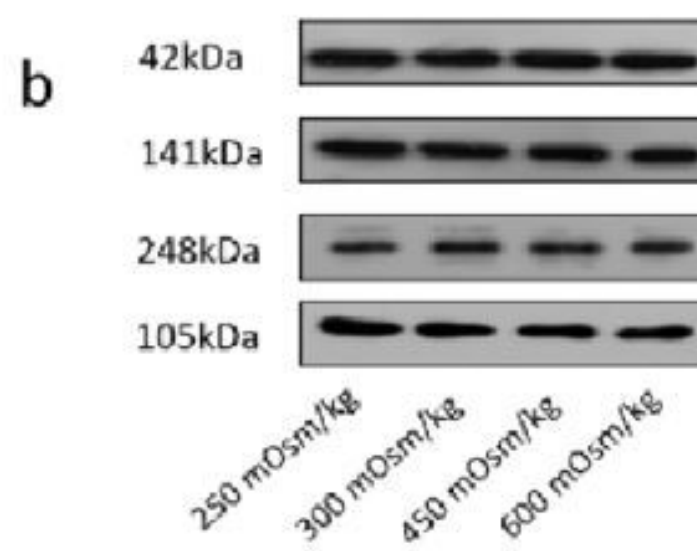

Aggrecan
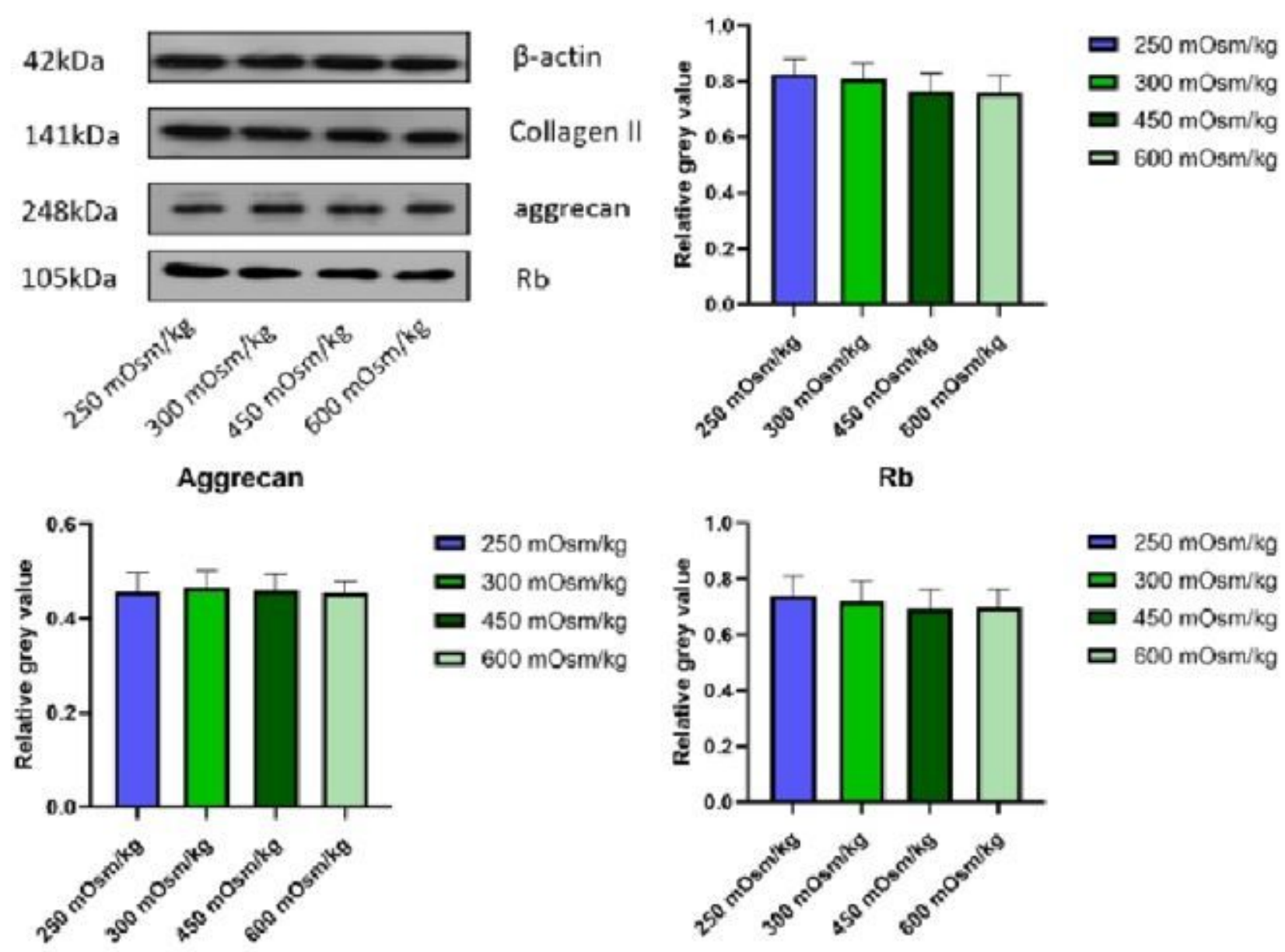

Rb

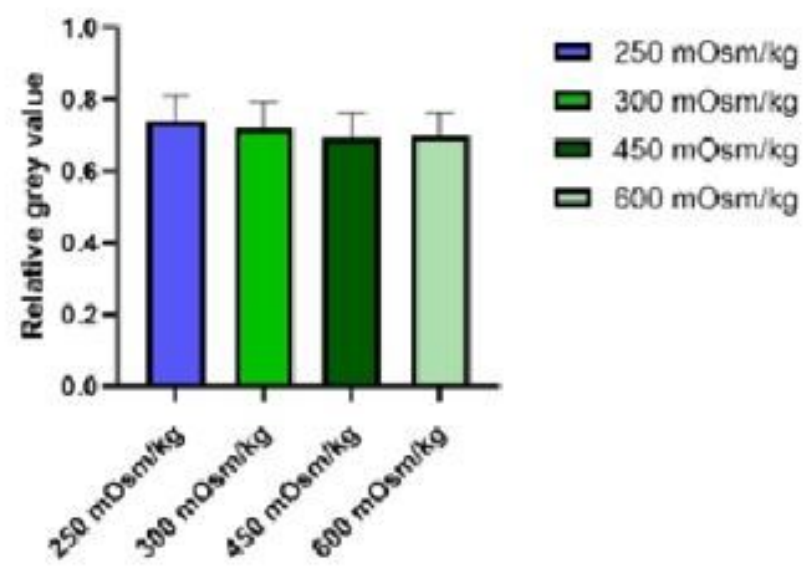

Figure 12

please see the Figure file in the Supplementary section for the full caption

\section{Supplementary Files}

This is a list of supplementary files associated with this preprint. Click to download. 
- figure.docx

Page 28/28 